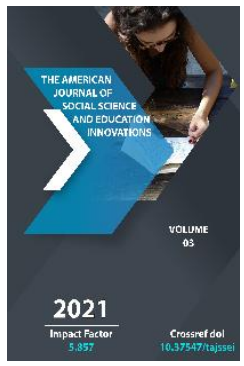

\title{
Phraseologys Formed On The Basis Of A Comparative Model (On The Example Of Uzbek-Korean Phraseologism)
}

\author{
Olmoskhon Erkaboevna Niyozova \\ Teacher, Department Of Oriental Languages, University Of World Economy And Diplomacy, \\ Uzbekistan
}

Journal Website:

http://usajournalshub.c

om/index,php/tajssei

Copyright: Original content from this work may be used under the terms of the creative commons attributes 4.0 licence.

\section{ABSTRACT}

A large-scale study of linguistic problems from the point of view of comparative linguistics and linguistic translation poses new common challenges for the science of the 21st century. One such problem is the study of translated texts from an anthropocentric position. Anthropocentric study of translated texts means showing the uniqueness of a particular people. In this article, research work on phraseology, formed on the basis of a comparative model, and, therefore, "similarities" in a particular language and culture, reflect the way of thinking and imagination of this people in the texts of the Uzbek-Korean and Korean-Uzbek translation. Linguistic and cultural comparative study of "phraseology" - one of the most important aspects of the topic.

\section{KEYWORDS}

Phraseological fund, artistic comparison, alternative, comparative.

\section{INTRODUCTION}

In every national language there are such stable expressions that create the emotional and figurative nature of artistic speech, the emergence of which is strongly associated with the views and attitudes of people to things and events in nature and society.: People use 
linguistic means based on various comparisons to express their the attitude to the world of things and events is figurative, emotional, exciting. The person, object, character, event, and landscape depicted are often exaggeratedly compared to familiar images. As a result, the image becomes clearer, the imagery of expression increases, high emotionality and emotionality are created.

It is well known that artistic comparison is usually based on the object of comparison, the object of comparison, as well as the signs and symptoms that make up the comparison. In other words, the first component of comparison, which is part of a quality category, is usually used in its main, central sense and refers to the sign or attribute on which the comparison is based. The second component, belonging to the category of horses, figuratively expresses what a person or a certain thing and event is compared with.

In the scientific literature, stable expressions based on artistic comparisons are called comparative phraseological units. The comparative type of phraseological units deserves special attention. Since "stable analogies are one of the brightest figurative means of solving the riddle of national consciousness", "the vision of the world from a unique national point of view is reflected in the semantics of analogy." Comparative phraseology constitutes about $60 \%$ of the phraseological fund of the language.

Stable analogies exist in different numbers in almost all languages of the world, and they are based on a single comparative model with a fairly uniform linguistic-logical structure, which opens the way for the inclusion of these expressions in the list of general linguistic structures. universals. But such analogies are unique to each language, as they reflect the national vision and national understanding of the peoples of the world.

We can say that stable analogies form a separate group of phraseological expressions in the language system, and they are introduced into speech with sufficient readiness. Such analogies are selected and used in the speech process in accordance with the communicative-aesthetic intention of the speaker, in order to ensure the effectiveness of speech as units with different levels of expression.

In Uzbek, "to be who you want" means to be, in Korean language 마음과 같다 expressed in comparative phraseology.

At that moment, two young men came out of Eshan's door.

"Oh, the street is so dark!"

"Tell me, there's not a single star in the sky for medicine!"

- You can go. It's been a frustrating night for me. "Yes, I feel sorry for the girl." (Abdulkhamid Cholpon. Tulip in the snow).

Compare:

어느 새 이맘 집에서 어린 남자 두 명이 나왔다.

- 어휴, 거리가 너무 어둡잖아!

- 그렇지, 하늘에 별이 하나도 없다.

- 오늘 밤이 이맘 할아버지의 마음과 같다.

가자.

- 네 말이 맞지만 그 여자가 안타까워. 누구의 아내가 되었는가!

The comparative phraseology of water is widely used in Uzbek linguacultural in the sense of "no sound": But ... Merciful Lord! How did he know at that moment, even earlier, that 
so much effort, so much labor and suffering had to be done on his own to see Him? If only he knew ... My God, he's gone out of the way again! Of course, he was not alone. A woman carrying a baby next to her ... And literally a minute, no, half a minute, maybe a split second - their gazes met! The comrade said something, but Shokhsanam did not hear. The world was quiet as water. (Anthology of Uzbek stories of the XX century. T.-2009. P.590).

In the quoted passage, the silent comparative phraseology of the universe sheds water on the Korean language 세상 모두가 멈춘 듯이 translated as if the whole universe had stopped. 그런데 어떻게 이런 일이 벌어졌을까? 술탄의 앞을 샥샤남이 스쳐 지나갔던 것이다. 샥샤남 역시 이 세상 모두가 멈춘 듯이 느꼈다. (From 2oth century Uzbek stories세기 우즈베키스탄 소설 선집. T.-2014. P.191).

In Uzbek, phraseology is used to add salt to a wound. The following section provides a comparative version of this phrase:

From now on, I will make a saddle for my day so that I can hunt and have fun with it. As soon as I sell the saddle and receive the money, the days I spent with my wife, sons, my wife begin to fade before my eyes, and the wound becomes new, it's like sprinkling salt on the wound, and my color changes. When I return the money to the owner and break the saddle, I feel better and calm down a little, "the saddler said, ending his adventure. (한국인을 위한 우즈베크 전래 동화 모음집 우즈베크 이야기 2014.-P.150).
Comparative phraseology like salting the original wound in Korean 마음이 아프다 translates to a heartbreaking phrase that cannot be compared. As a result, the protagonist's grief is not fully revealed.

Compare:

그때부터 세월을 보내며 마음을 편하고 즐겁게 해보려고 안장을 만들고 있지. 그런데 안장을 팔아서 돈을 받자마자 내 아내와 아들들, 아내와 보냈던 시절이 눈앞에 떠올라 마음이 계속 아프고 상처가 더 깊어져. 그래서 안색이 바뀌어번다네. 돈을 돌려주고 안장을 부순 후에야 심란한 게 사라지고 조금 차분해져 (한국인을 위한 우즈베크 전래 동화 모음집 우즈베크 이야기 2014.-P.109).

Sometimes comparative phraseology in one language is an alternative to phraseology in another language that does not have an analogy mode. For example, in the Uzbek language, a comparative phraseological unit emanating from the "cup of eyes" means "anger is reflected in the eyes and the eyes are shining":

The king was furious, his eyes popped out of the cup, and he suddenly said, "Executioner!" (Flying carpet. 한국인을 위한 우즈베크 전래 동화 모음집 우즈베크 이야기 2014.-P.128).

The same phrase is used in Korean, 화가 나서 눈을 부릅떴다가 but does not include the comparison module. 
임금은 화가 나서 눈을 부릅떴다가 바로 “망나니!” 하고 소리쳤다 (한국인을 위한 우즈베크 전래 동화 모음집 우즈베크 이야기 2014. -P.86).

From the point of view of the semantic and methodological function, only the main components of the respective alternatives are similar to each other, while the other words are different. Such interchangeable phraseological units are usually intended for the figurative or emotional expression of the same event, action or character trait and are fully compatible with each other.

In Korean linguistics, the comparative phraseology "cat-dog" 개 고양이 보듯 is used to refer to people who constantly fight, quarrel, and live like enemies.

This is an alternative to life as a dog and a cat in Uzbek linguistics. However, this phrase is not considered a comparative phraseology, since it does not contain analogies.

Some Uzbek phrases can be an alternative to comparative phraseology in Korean. For example, the phrase "honoring someone" is an alternative to the comparative phraseology "honoring the queen" in Korean.

"Well, I'll carry it in your hand", - said my brother. Please ... at least talk to him (Z. Kurolboy kizi. An old song. Anthology of Uzbek stories of the 20th century. T., 2009. P.592).

우리 형과, 우리 동생과 결혼하라고. 만일 승낙하지 않으면 몰래 납치할수도 있다고. 결혼만 해주면 왕비처럼 모시겠노라고 (From 20th century Uzbek stories세기 우즈베키스탄

소설 선집. T.-2014. P.192).

You may notice that stable connections in the original text are sometimes translated using comparative phraseology in order to enhance the image, expression and image in it. For example, in A. Cholpon's story "Tulip in the Snow" the phrase "house in the snow" is used to describe a very negative attitude towards Samandar, who concluded his 17-year-old daughter Sharofatkhan in the arms of an old man with two wives. The translator described a strong negative attitude towards the phrase, comparing the behavior of the animal's father to that of the animal in order to adequately convey this to the Korean reader:

What do you say, let your father's house burn down, he's not a man!

"Look how he pulls a girl out of the car, like his granddaughter, with a white beard." I wanted to look like this, but I couldn't!

Translated:

-그래, 그녀의 아버지는 동물 같다! -수염이 하애졌는데도 소녀 같은 여자를 데리고 가는 모습은 참을 수 없다.

Stubborn phraseology in Uzbek means "upset". When used in the form of neck stiffness, this is comparative phraseology:

"Peace be with you," I said.

"Why are you walking so fast?" he said. Where is the honor! As if he didn't know me.

"No, look at the speedometer," I said.

- I see. Three sum. 
"Everything is fine." Paid:

"Is the owner healthy?" I said. He stared at me stubbornly.

"The owner has left," he said.

"Where to?"

"Back where he came from ... do you understand?" Yesterday they were removed from the party. He was fired today (Sh. Kholmirzaev. Green "Niva").

The comparative phraseology in this passage has been figuratively translated into Korean as facial expressions:

“안녕하세요?” 앞으로 갔다. “왜 속도가 그렇게도 빠릅니까? - 하고 물었다.

그는 이번에는 경례도 하지 않았다. 나를 모르는 척 했다. “아니요, 속도 계기판을 보세요.” 라고 했다. “보고 있어요. 속도가 높아요. 삼만 숨이에요.” 라고 했다. "알겠어요, 알겠어요." 돈을 주고 “원장님께서 잘 지내고 계세요?” 하고 물었다. 그는 나를 보고 표정이 바뀌어졌다. "원장은 갔습니다." 라고 했다. “어디로요?"

“가야 될 정소로 갔어요. 알겠어요? 어제 정당에서 제적 당했었어요. 오늘 직장에서 해고 되셨어요." (From 2oth century Uzbek stories세기 우즈베키스탄 소설 선집. T., 2014. P.102-103).

\section{CONCLUSION}

Stable expressions based on comparisons are called comparative phraseolo-gical units. Comparative phraseology makes up about 60\% of the phraseological fund of the language. The comparative phraseology of the Korean and Uzbek lan-guages is based on a single comparative model with almost the same linguistic and logicalstructure.

\section{REFERENCES}

1. Jo'raev M., Sattieva D. The tree of life in Uzbek folklore. -Tashkent: Fan, 2010.

2. Djuraev M., Shomusarov Sh. Uzbek mythology and Arabic folklore. -Tashkent: Fan. 2001.

3. Iskhakov Yo. Tashbeh // Uzbek language and literature. № 5. -Tashkent, 1970.

4. Makhmudov N. Looking for ways to study the language perfectly ... // Uzbek language and literature. -Tashkent, 2012. -№ 5. -B. 316.

5. Makhmudov N. Analogies are a product of figurative thinking // Uzbek language and literature. № 3. -Tashkent, 2011.

6. Makhmudov N. Similarities and national image // Uzbek language and literature. № 1. -Tashkent, 2013.

7. Usmanova Sh. The role of analogies in creating a linguistic landscape of the world // Oriental Studies, №1. -Tashkent, 2015.

8. Usmanova Sh. Linguocultural aspects of translation. -Tashkent: ToshDShl, 2015.

9. Eshonkulov J. Folklore: image and interpretation. - Against: Nasaf, 1999.

10. Ismatullayeva, N. R. Translation of phraseological units in Chinese and Uzbek languages. In Scientific research of the SCO countries: synergy and integration (International conference). Beijing, PRC, June (Vol. 24, pp. 45-50). 